\title{
The Paradox of Czech Crusaders: Will They Ever Learn the Corruption Lesson?* (Corruption and Anticorruption in the Czech Republic)
}

\author{
Lubomír Lízal and Evžen Kočenda \\ CERGE-EI, Prague, Czech Republic \\ W. Davidson Institute, University of Michigan Business School, USA \\ CEPR, London
}

\begin{abstract}
:
Corruption has a negative impact on society and economy. The transition process in Central and Eastern Europe (CEE) uncovered dormant possibilities for corruption and necessity for appropriate steps to be taken. We document the state of corruption in the Czech Republic and the measures introduced to fight it. We cover sectors of society and economy according to their importance of a consequential corruption hazard. We also described the government's program of anticorruption and its achievements and failures. The state of corruption in the country, measured by the Corruption Perception Index, presents a serious problem since the index does not improve as the transition process advances. Numerous comparative studies, however, suggest that corruption is more prominent feature in a number of other transition countries. We believe that the substantial change of approach to the institutional framework is necessary in order to prevent and fight corruption successfully.
\end{abstract}

Abstrakt:

Korupce má negativní dopad jak na ekonomiku tak společnost. Transformace ve střední a východní Evropě odkryla latentní možnosti korupce a nutnost odpovídajících protiopatření. V článku popisujeme současný stav korupce v ČR a přijaté kroky. Popisujeme jednotlivé oblasti rozdělené dle důležitosti korupčních důsledků a vládní protikorupční program s jeho úspěchy i neúspěchy. Stav ve společnosti se s postupující transformací nelepší nebot' index míry korupce má soustavně negativní trend. Mnoho srovnávacích studií však uvádí, že korupce je větším problémem v řadě jiných transformujících se zemích. Změna $\mathrm{v}$ celkovém př́stupu a ve výstavbě legislativního rámce je nezbytná, aby byl boj proti korupci úspěšný.

Keywords: corruption, institutions, transition, hidden economy, state administration

JEL Classification: H50, I20, K42, O17, P27, Z13

An earlier draft of this paper served as a background study on corruption and anticorruption issues in the Czech Republic for the volume entitled Anticorruption in Transition: A Contribution to the Policy Debate, published by the World Bank, Washington, DC, 2000, ISBN 0-8213-4802-7. The authors acknowledge support of the World Bank, CERGE-EI, and the William Davidson Institute at the University of Michigan Business School during their research on this paper. The usual disclaimer applies.

\footnotetext{
* In the late middle ages the Czech Kingdom was at war with most of Europe since it was unsatisfied with the status of the Church, namely its corrupt policy of selling indulgences. The crusaders were not able to defeat the Czechs for a long time. Nowadays it is the opposite: the Czech Republic is heading for the EU and the EU is afraid of the possible corruption entering it along with the candidate countries.
} 


\section{Introduction}

It is widely acknowledged as well as supported by numerous studies that corruption has a negative impact on economy and society. The economic and social transformation in Central and Eastern European (CEE) countries inevitably created and enhanced opportunities where corruption could easily flourish. Corruption in the transition countries has become more severe as these countries increase their openness and involvement in international communities and organizations. This analysis aims to document the state of corruption in the Czech Republic and the measures introduced to fight it.

With a dramatic change in the Czech political regime in 1989, the whole process of social and economic transformation initiated changes in the environment of corruption. There exist particular shifts in corruption from one area to another that occurred along with economic and legal transformation, which sometimes led to a growth in large-scale corruption. Corruption shifted primarily from the sphere of general services and sales to the region of state administrative services.

In order to understand the evolution of corruption under the new conditions of the transition process we have to tackle, at least briefly, the historical roots and origins of corruption. A comparison with corruption common under the communist regime, which was based mainly on mutual friendly services, and time dependent evolution of corruption, shows that the legislation was quite appropriate to punish classical bribery and corruption of state officials. It was, however, completely inappropriate to prevent the newly emerged forms of corruption associated with rent seeking.

Moreover, the former approach based on the services, small gifts, and small financial bribes has sustained up to date, and is the norm of behavior and negotiation in state administration. In the past, the general public perceived any part of the state administration as a repressive body. Since the state was an "enemy," small-scale misuse and theft of public goods and services became part of the passive opposition against the communist regime. Of course, after forty years such behavior had to become not only a socially acceptable norm but sometimes a norm of behavior.

Notably, the general public does not perceive state administration at any level as a socially prestigious and valuable occupation. The income of the administration is relatively low and almost no income differentiation exists. Consequently, the state administration is not a competitive job opportunity on the labor market, and does not attract skilled people. With administrative staff who is often unqualified and unable to make independent decisions the prevailing tendency is to delegate responsibility to resolve pertinent matters to a higher level administrative structure. In addition, clerks often compensate their feelings of non-importance with unfriendly behavior and bureaucratic rigidity towards the general public. All state administration requires that citizens use specific parts of the administration according to their residency status. This means that not only the procedure depends on the interpretation of rules by 
the regional (local) office but also that citizens cannot use administration in another region. Furthermore, semi-private institutions, like major health insurance companies, are mimicking the state administration behavior.

These roots might be the main reason why recent changes, which are presented to the public as a harmonization with the EU norms, represent a visible increase in the power of state administration in its discretionary decisions. ${ }^{1}$

With this account in mind we can divide corruption, albeit somehow artificially, into two dominant forms:

\section{High-level corruption involving elected and senior public officials.}

This category covers, in particular, financing of political parties and their election campaigns, parliamentary lobbying, and public tenders at any level of state administration. Lobbying, at high-level administration does not generally contain features of the transparent process often found in Western democracies. Instead, it resembles rent seeking activities of political and business influential groups. Rose-Ackerman (1999) provides a comprehensive analysis of the relationship of corruption and government, specifically in cases of corruption that occur at the highest levels of government and involve major government projects and programs.

\section{Low-level corruption involving mid and low level bureaucrats.}

This classification refers to municipalities and all forms of public service provided by the state through regional and local agencies, as well as state guaranteed health care. Such a level also entails informal links among private companies and low-level state bureaucracy. According to the recent EBRD survey (EBRD, 1999), the main obstacles to the growth of small and medium enterprises (SME) are anti-competitive practices and corruption, followed by taxes and business regulations. A priority for the next decade of transition is to embrace competition policy that focuses on reducing barriers to business start-ups, introducing measures to combat corruption and crime and hardening the budget constraints on declining industrial enterprises. Lizal and Svejnar (2000) show that problems with soft-budget constraints persist in the Czech economy, mainly via the banking sector. Thus, credit related corruption possibilities are well warranted and need to be studied.

Further, spread of corruption embraces direct economic activities as well as less direct ways through the administrative processes. On the macroeconomic level the costs of corruption should be emphasized in terms of economic growth. During the transition process the fight against corruption is expensive and cannot be seen as being independent from the reform of the state. If certain reforms are not made, corruption is likely to continue to be a problem regardless of actions directly aimed at curtailing it.

\footnotetext{
${ }^{1}$ For example, there are proposed changes in the hunting law to prevent poaching. The new law would put the status of hunters on the same level as that of policemen, however, without the qualification requirements the police must meet.
} 
The comparison of the relative influence of corruption of state bureaucrats on the enterprise undertaking is outlined in Figure 1, where the estimated shares of firms' annual revenues used for unofficial payments "to get things done" are plotted (World Bank, 2000). The comparison is based on a survey conducted on the basis of face-to-face interviews with firm managers or owners during the period June through August 1999 in the listed countries. In each country more than 100 firms were interviewed. Larger samples were used in Poland, Ukraine, and Russia. The samples were fairly representative of the domestic economies with specific quotas placed on size, sector, location, and export orientation. We can see that the Czech Republic, together with Slovakia, is regarded as the least favorable among the Central European countries after Russia.

Figure 1. Administrative Corruption:

Bribes as a share of annual revenues per firm.

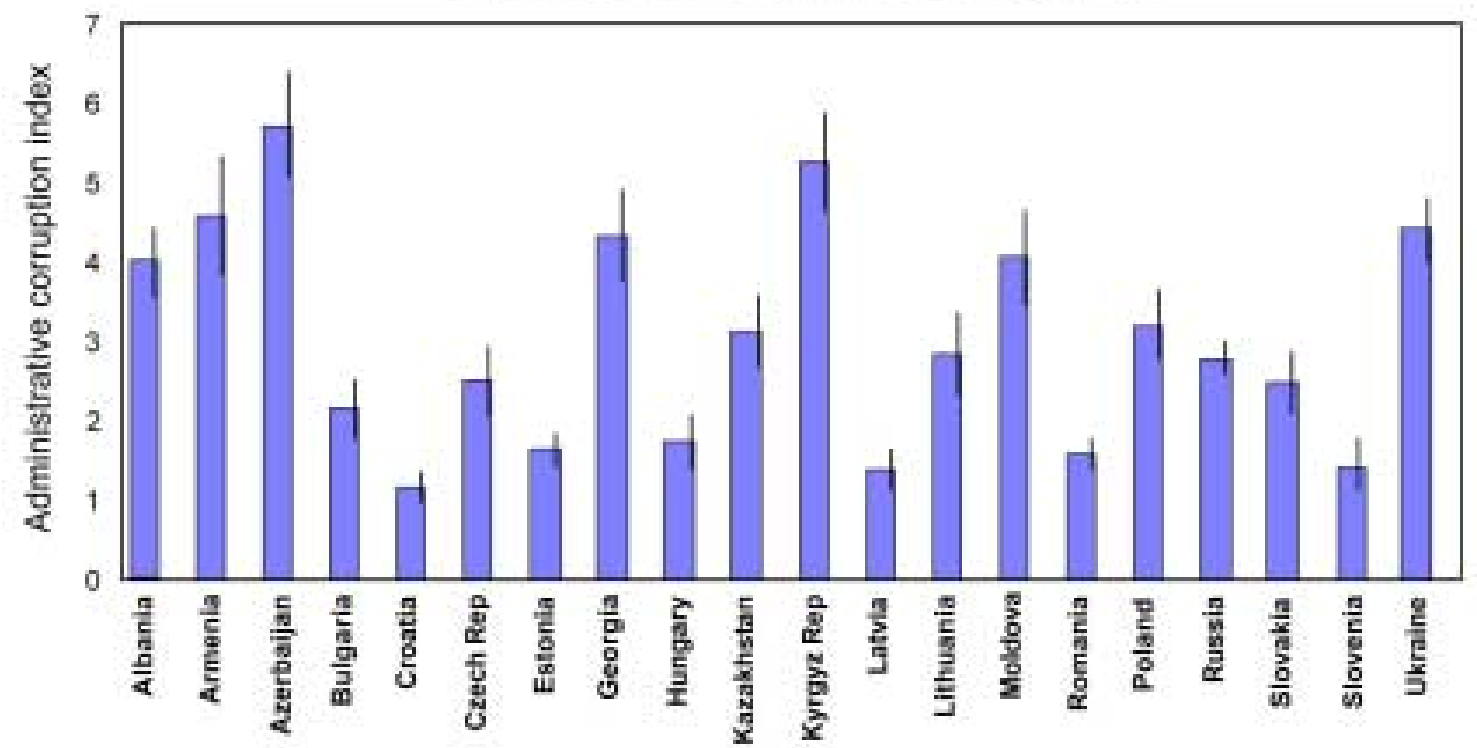

Note: The thin line at the top of each bar represents the statistical margin of error based on a standard deviation. Source; World Bank (2000)

\section{Sector Comparison of Dominant Forms of Corruption}

We now proceed with a classification and description of the dominant forms of corruption according to the different sectors of society where corruption appears.

Although all forms of corruption are socially and economically dangerous, we can divide the sectors into four groups according to their importance in the prevention of corruption and consequential hazard to society. The first group consists of sectors, which were also designed to fight corruption and to guarantee legal status. The second group consists of various methods of state administration. The third area consists of services provided by the state and society to the general public, and the fourth involves the private sector. 
Despite the fact that we provide the possible means of corruption, there is little evidence in criminal prosecution of all these forms. Therefore, we include major known cases as illustrative examples whenever possible. Our division is made in such a way that the members of a subsequent category have more incentive to corrupt the members of the preceding one. Therefore, the hierarchy we use describes mainly the methods of receiving bribes. However, one should keep in mind that corruption is not a strictly one-way process.

Table 1 illustrates how the perception of bribery by ordinary citizens has changed over the first decade of the transition process. The results are taken from GfK (1998). Two major changes are immediately visible. Services and sales in general, e.g. all categories that were already almost completely privatized, show a dramatic decline in perceived corruption. State administration, on other hand, records an almost tenfold increase in corruption perceived by citizens.

Table 1

Question: In Which Area is Bribery Most Prevalent? (by \%)

\begin{tabular}{|l|c|l|c|}
\hline \multicolumn{1}{|c|}{ Sector } & 1989 & \multicolumn{1}{c|}{ Sector } & 1998 \\
\hline State Administration & 3 & State Administration & 31 \\
Sales and Repair & 11 & Judicatory System & 15 \\
Health Services & 21 & Health Services & 15 \\
Transport, Construction Materials & 5 & Police & 9 \\
Services & 31 & Services & 9 \\
Education & 1 & Education & 2 \\
Restaurants & 3 & Restaurants & 2 \\
Retail Sales & 26 & Army & 0 \\
\hline
\end{tabular}

*Source: Výzkumný ústav obchodu, 1989, N=1643, data for Czechoslovakia.

**Source: GfK - Praha, April 1998, N=967, data for Czech Republic.

Based on the above comparison of categories where bribery may occur the following hierarchical division of corruption can be observed:

1. Police, State Prosecution, Judicatory and Court Systems including Parliament and Government,

2. Tax and Fiscal Authorities, Licensing Laws and Procedures, Public Tenders, Monopoly Regulation, and State, Local and Municipal Administrations,

3. Education, Health Care, and Social Care,

4. Private Businesses and Citizens.

All the institutions, with the exception of private firms (fourth category), are fully or partly financed through public budgets. There is always a possibility for the representative of a group to try to corrupt any member(s) of the previous (upper) category to increase either financial means allocated or competence on usage of the allocated funds. One of the main 
reasons for the presence of corruption in private businesses is the persistent presence of softbudget constraints.

In the following subsections we list the possible methods of corruption for each part of the above.

\subsection{Police and Investigation}

A major sustaining conceptual problem prevails from the communist past, and is common to both the general public and state administration. The police are still viewed as a repressive part of state administration and not as a major contributor to crime prevention and their authority and public appearance are perceived only to keep public order.

In particular, the most susceptible to the low-level corruption are those sections of police that are in direct contact with general public. The main reasons for corruption include inadequate incentive schemes, inadequate technical equipment, and in certain cases undefined legal status, poor management and control, and poor management of human resources and qualifications.

All corruption in the police involves the misuse of power while not each misuse of power involves corruption. The exact form of corruption depends on the specific situation and varies within the specific departments (criminal, traffic, foreign and border service, and so on). The most visible part involves traffic police since traffic fines (especially those for speeding) are more or less arbitrary and certain fines are collected on the spot.

We can identify two basic types of police power misuse related to corruption. The first involves the various forms of crime cover-ups. The second is just the opposite: finding nonexistent criminal acts in the anticipation of possible promotion and pay rise. The aforementioned form of corruption starts from receiving free services, slow acting or inaction during investigation, racketeering, providing cover for criminal acts, hiding the evidences, protectionism, and providing information on the status of a criminal investigation. In 1999, 345 policemen were investigated for more than 500 criminal delinquencies. The highest proportion of police delinquencies was found among officials under the age of 29, with services shorter than 5 years (report of the Police for 1999).

\subsection{State Prosecution (State Attorney Offices)}

State prosecution is designed to monitor investigations and to decide whether an indictment should be filed or not. A prosecutor at a higher level can always override the decision of a lover-level prosecutor. Such controlling mechanisms make the possibility to corrupt more complex and hence the corruption is less likely. On the other hand, the prosecutors' decisions can waste a police investigation and a corrupt high-level prosecutor can virtually paralyze the system. A specific feature is that prosecutors can decide independently of each other. This, of course, opens a space for corruption, especially in cases where the interpretation of the law is not straightforward. 


\subsection{Judicatory and Court Systems including Parliament and Government}

The judges are independent of the state in the Czech Republic and only the law limits them. Such a feature makes their decision making independent of the interests of any group. On the other hand, the tradition in the decisions is to focus more on the formal aspects of the case than to interpret the law (extensive interpretation).

This is driven not only by the nature of Continental law but also by historical tradition. The decision making in transition periods when the laws are not adequate to the rapidly changing environment, has severe limitations compared to the case-law approach, or at least, more extensive approach in the case judgement.

Looking at the recent past, vast amounts of legal economic cases would be considered illegal in the West (for example, so-called Ponti's scheme and others) while Czech legislation does not explicitly mention these types of behavior as illegal. Therefore, the whole Czech stock market became almost worldwide infamous because of its lack of transparency, price manipulation and abuse of power by shareholders with majority stakes. Although the situation improved when the Exchange and Securities Commission was established and new laws were approved by Parliament. ${ }^{2}$

The current government has declared its interest to fight corruption and its program "Clean Hands" was a major election topic. ${ }^{3}$ On the other hand, its effort can not be seen as fully credible. Both major parties in the Czech Republic, social democrats and civic democrats, are under investigation for use of illegal funds, misuse of economic information, and tax evasion. ${ }^{4}$

As a final note, unfortunately there is quite a lot of lobbying in the Lower House of Parliament. We can ascertain this based of the amendments and modifications suggested (and approved) during the final (third) reading. These modifications become a part of the new law (if accepted) even although they were not mentioned during previous readings. A perfect illustration is the Property Execution Act. The intention of the law was to allow better debt repayment in cases of default and indirectly to speed up the bankruptcy procedures. However, in the third round all firms were excluded so only citizens' properties could be levied on.

\footnotetext{
${ }^{2}$ The initial attitude towards the privatization process and the regulation of the stock exchange can be illustrated by a controversial statement made by former Minister of Finance, Mr. Klaus: "I do not know a method to distinguish dirty and clean money in practice; to do so would mean to cast doubts about the process of small privatization, I think it would not be a good decision", in an interview for the Czech Press Agency (CTK), September 27, 1991.

${ }^{3}$ More on this can be found in other section.

${ }^{4}$ Former Minister of Finance in the current social democrats' government is investigated for asset stripping. A former minister responsible for EU coordination was found to have illegal deposits abroad and is suspected of receiving provisions and tax evasion. Moreover, one of the Prime Minister's advisors was publicly accused of blackmailing and the case is under investigation. Civic democrats are suspected of illegal financing, Swiss police confirmed this suspicion in part by acknowledging the existence of a suspicious account in one Swiss bank, investigation is still under process.
} 


\subsection{Tax and Fiscal Area}

The Czech laws are quite strict in the collection of income taxes and there are only a few possibilities for leakage. However, there exists small groups of officials at the Ministry of Labor and Social Affairs and at the Ministry of Finance who can forgive fines for late payment of taxes and social security. The decisions are in reality made ad hoc; the procedure has no rules that would describe the process and therefore justify the exceptions granted. Moreover, the existence of such groups is not known to the general public, hence, the citizens (small ordinary taxpayers) do not know that they can apply for a pardon.

Although the tax law is quite transparent, the associated laws on health insurance and social security are more complex and less transparent. The employees do not see from their paychecks that two thirds of the social and health payment is constructed as a payroll tax and directly paid by the employer. An opinion poll held on this topic by the STEM agency in 1998 indicated that, according to respondents, the rich should pay higher taxes, about $25 \%$ of their net income. Such a perception is in sharp contrast to reality since at that time the high-income brackets defined tax payments as $39 \%$ of net income. An illustrative example of average shares of income tax, various taxes like payroll and a net income, can be found in Turnovec (1999).

The remaining segments of the fiscal system and administration are more problematic. There are quite common frauds in value-added tax (VAT) collection and the collection of consumption (excise) taxes and custom duties. These frauds are estimated in billions of Czech crowns $(\mathrm{CZK})$ with links to international crime. ${ }^{5}$ In this area we face not only corruption but also highly organized international criminal activities. A popular scheme in the middle of the 1990's can serve as a good example. Imported oil (petroleum) products were declared for heating purposes but in reality were used for truck fuel. The unpaid consumption tax comprised of more than one half of the final sale. The total state revenue from truck fuel consumption tax was 17.5 billion CZK in 1996 and the loss in tax revenues was estimated at 2.5 billion CZK. Of course, such activity required at least a passive attitude by the state administration.

During the first half of the 1990's the evasion from payment of consumption tax on alcoholic beverages and cigarettes was alarming. Currently, each pack of cigarettes has to have a fee stamp and the method of stamping is under consideration for alcoholic beverages as well. Additionally the value-added tax is misused for tax crimes. According to the tax law the financial office (i.e., the state) has to refund the VAT to the exporter. Therefore, fictional exports, or overvalued exports, can generate substantial cash.

All these mentioned crimes require at least passive cooperation of the tax authority or custom authority, which is also a part of the fiscal administration. Quite common are cases of imports, which have a declared low value to reduce import duty. The most prevalent cases were the imports of used cars where the declared custom value was estimated to be only one tenth of the real value.

\footnotetext{
${ }^{5}$ Similar cases were reported to occur in Poland and Hungary.
} 


\subsection{Licensing}

Licensing is used to regulate access mainly in areas of telecommunications, radio and television broadcasting, insurance and finance, foreign trade with selected commodities (armaments or goods with existing import quotas), and mining. The procedure of licensing should be transparent and, if possible, single-criteria, or the selecting criteria of multi-criteria tender should be at least an integral part of the license provided. There are well-known cases from the past where the license procedure resulted in a suspicious conclusion.

\section{Banking and Finance}

At the beginning of the transition the state allowed new entries and it became very easy to receive a banking license. All new small banks had liquidity problems or were tunneled and had to merge or go bankrupt. The state responded by freezing the issue of new licenses instead of a more professional and prudent regulation. Only later the banking sector regulation became more advanced.

The investment funds, newly established during voucher privatization, became, with several exceptions, a synonym for asset stripping and abuse of small shareholders. There existed no effective regulation of investment funds. The complete lack of stock market regulation speeded up the process of dishonesty through obvious price manipulation. This is also a reason why there is strong opposition to the existence of a compulsory private pension fund scheme, although the pay-as-you-go pension system is getting into huge deficit and the prospects looks bad.

The situation on the insurance market is more optimistic despite the fact that the regulation is quite similar to that used for investment funds. So far only one insurance company has gone bankrupt. On the other hand, the market is still not fully open and licensing is limited.

\section{Telecommunications}

The monopoly fixed line provider has had its exclusive rights granted till January $1^{\text {st }}$, 2001. The reason is that in the past the fixed line network required enormous investments. Therefore, during the privatization process a strategic partner was selected and in exchange for a commitment to build and modernize the network such exclusivity was granted. As an experiment, in several regions small local companies were licensed to provide the fixed lines, however the incumbent controls $99.9 \%$ of all lines (OECD, 1999).

The exclusive right on building the fixed end-line network was questioned in the past since it may slow down the speed of wiring the whole country. However, no direct evidence was found although the case was reopened by the press during the investigation of illegal sponsoring of political parties.

In 1999, a third license for a mobile telephone (GSM) provider was granted. Although the 
license was based on multi-criteria choice, certain promises are not part of the license conditions. Moreover, the winning pricing scheme offered in the tender is handicapped by additional disadvantageous conditions, like cash deposits or long-term interminable contracts.

\section{$\underline{\text { Radio and TV Broadcasting }}^{6}$}

A classical example of high-level lobbying is the case of the free terrestrial license. The original tender involved many criteria. The license was granted to the firm that offered low price and a program having intellectually higher standards than the (state) public TV broadcast. Once the license was granted, the law was changed in a way that the program composition is not a part of the license and the TV company became highly commercialized. Quite recently, an open fight for the complete control of this highly profitable firm started between the Czech license holder and a foreign investor. Fortunately, there exists a sufficient amount of radio frequencies to grant enough licenses to prevent the above situation in radio broadcasting.

\subsection{Public Tenders}

Most cases of corruption that are disclosed in the media are connected with public tenders both at the state and municipal levels. Pre-selection of the prospective supplier is one of the most cited flaws. The selection of the pre-selected firm to sign a contract is done by the means of custom-made conditions in the tender, custom tailored weighting of criteria or even by changing the tender conditions during the tender process. Such non-standard behavior is highly susceptible and opens broad opportunities for corruption to materialize. The available means to disclose a possible manipulation in the aforementioned schemes are quite limited.

Such a behavior during transition is in line with the exposition of Acemoglu and Verdier (2000) who argue that room for corruption is created by transferring resources from one party to another by government interventions. As corruption often undermines the purpose of the intervention, the government tries to prevent it. By doing so it may create rents for bureaucrats, induce the misallocation of resources, and increase the size of the bureaucracy. Preventing all corruption is excessively costly and may involve a certain fraction of bureaucrats accepting bribes. Moreover, Stiglitz (1999) argues that privatization created an opportunity to collect all expected future bribes in their discounted value at the time of privatization.

Public tenders that lead to public investments may have a negative economic impact due to corruption associated costs. Equally important is an impact on the economy in general. Tanzi and Davoodi (1997) argue that corruption, particularly political or "grand" corruption, distorts the entire decision-making process connected with public investment projects. The degree of distortions is higher with weaker auditing institutions. They present evidence from various countries that higher corruption is associated with higher public investment, lower government revenues, lower expenditures on operations and maintenance, and a lower quality of public infrastructure. The evidence also shows that corruption increases public investment while

\footnotetext{
${ }^{6}$ A special law governs Czech Television (as a public service).
} 
reducing its productivity. These are five channels through which corruption lowers growth. These findings are supported by Mauro (1995) who investigated the impact of subjective indices of corruption on economic growth and found supportive evidence that corruption lowers investment, thereby lowering economic growth. Therefore, in countries with high corruption, very high public sector investments should be evaluated with caution. Since the total aggregate investment to GDP ratio in the Czech Republic is one of the highest among the CEE countries (CESTAT, 1999), the argument made by Mauro could be applied for the Czech Republic as well.

\subsection{Monopoly Regulation}

As in the cases of public tenders and licensing, the state uses chiefly discretion to regulate the monopolies (Lizal, 2000; Kočenda and Čábelka, 1999). In addition, there exists no independent regulator or regulatory office. Although the existing regulatory institutions are formally independent, they are financed by and subordinated to the founding (supervisory) ministry. According to the law and existing regulations, any disputes should be settled either by the ministry or by the regulatory office. Such an institutional arrangement will have to be abolished with the accession to the EU.

In most of the network industries the state controls the majority stake in the utilities companies (Kočenda, 1999). On the other hand, the state should behave as an independent regulator, which creates an obvious incentive problem. Such a problem cannot be solved independently on the state. Of course, the absence of clear rules opens up the space for higher level corruption, although there are no proven cases. In addition, almost every monopolistic provider has to have a license. This applies not only on large utilities but also on small local monopolies like local heat suppliers.

Regulatory issues were extensively discussed by Johnson, Kaufmann, and Zoido-Lobatón (1998) who recently used cross-country regressions to explain the size of the unofficial economy in regions of Latin America, OECD countries, and transition economies in the Central and Eastern Europe (CEE). They found evidence that countries with more regulation tend to have a higher share of the unofficial economy in total GDP. They also found that a higher tax burden leads to more unofficial activity and countries with more corruption tend to have a larger unofficial economy. Findings of Lacko (2000) support such a view with evidence from the transition CEE countries. Stagnation or further increase in the size of hidden economy was experienced in the economies of the former Soviet Union, while an explicit declining tendency could be seen in more advanced transition countries.

\subsection{State, Local and Municipal Administrations}

Earlier in the text it was mentioned that the public administration is still not perceived as a service to the general public paid by the taxpayers but as an annoying structure to be tolerated and dealt with only in the case of necessity. What is felt as a major flaw of the administration is that frequently the officials seek reasons why not to proceed. They search for bureaucratic 
mistakes and do not seek methods on how to help the asking citizen to achieve his/her goal. Currently the administration proceeds only if the action is explicitly permitted by the existing regulation. The logic would suggest proceeding in all cases that are not explicitly forbidden or illegal.

As a final illustration we provide a quite frequent, although not fully legal, practice used during renovation or construction of family houses. It is actually easy to start the construction work without a permit and then ask the District Construction Office for a subsequent permit with a small fine to be paid. The risk of not getting the permit is extremely low and this method is often easier than to ask for all the permits before construction. Such behavior perversely saves a lot of time and, hence, money.

Another area of behavior apt for potential corruption concerns local authorities. The local administration, especially municipalities, often put state or municipal property as a collateral to back a third person's private loans. Such behavior is not only highly questionable but also creates opportunity for corruption to emerge. In this context, the sale of a part of a National Preserve on a municipal territory serves as a flagrant example.

\subsection{Education}

A major problem of higher education (except for the lack of finances) is its limited supply. Certain fields at universities or high schools face excessive demand, which is up to ten times the capacity. Last year, there was a case at the Law Department of a major university, where entry exams were sold for CZK 100,000 (approx. \$3,000). No one was prosecuted or held responsible. The suggested yearly tuition is approximately ten times less than the aforementioned sum. Since the government is not in favor of introducing tuition fees at the state universities due to its possible social impact, the current situation paradoxically favors students from wealthier families. $^{7}$

Most higher education is still publicly financed. The private schools also receive a state supplement but lately the scrutiny for private schools to receive such a supplement became excessively harsh. Such conduct may result in reduced government spending on education in general. ${ }^{8}$ Furthermore, the other corruption possibilities include the preferential treatment or acceptance of selected students whose parents are able to pay extra tuition or to lobby for state finance.

\subsection{Health Care}

Historically, the Czechs are used to receiving health care as a free service provided by the

\footnotetext{
${ }^{7}$ We do not mention one's high moral standards as an obvious attitude towards obtaining entry-exam answers for money.

${ }^{8}$ Mauro (1998) argues that corruption is found to reduce government spending on education in a cross-section of countries.
} 
state. In the centrally planned era a limited health supply existed and caused the tradition of "gifts" for a service already received or to be received; the gifts ranged from flowers, books, coffee, and alcohol to money.

Health care is provided through a mandatory health insurance scheme. All terms of the insurance, including premium and coverage, are determined by the state. However, the payment of health insurance is still not generally viewed as payment for the health service but rather as a tax. Health providers are not viewed as (private) businesses providing care and being paid through insurance companies, but as a part of the state service. This is also caused by the nontransparent system combining taxes, health insurance, and various social insurance payments. Despite the fact that people view their health as a major asset, they do not often receive full information on the appropriate care needed and on its fair or real price.

Aside from the above, there exists pressure from the pharmaceutical industry toward use of more profitable drugs and there is no definition of the standard health care covered by the insurance as guaranteed by the law. The regulation is ad-hoc and usually even retrospective, sometimes punishing the provider for past efficiency.

To sum up, the patient is usually not able to:

1. recognize that the service is adequate and treatment is ethical,

2. realize that the service is too expensive or redundant, and

3. discover that the provider has charged the insurance company for non-performed services or non-supplied drugs.

On the other hand, the insurance companies are abusing their power. ${ }^{9}$ They pay late and the average overdue payment is well over two months. There exists a silent threat of contract cancellation from the dominant insurance companies towards the dependent health care providers. The providers are warned not to charge overdue interest and are even manipulated to sign agreement amendments that make the contract even more disadvantageous for them. Quite recently, the newly issued regulation worsened the situation, and the medical professional society claims that the change was adopted just to prevent the financial collapse of the state governed health insurance company. All this can be viewed as, at least, passive corruption.

\subsection{Social Care}

This area concerns mainly state unemployment policy. There are two state unemployment policies. The active policy when the financial resources are allocated for the creation of jobs, and the passive policy - the payment of unemployment benefits. The district labor offices govern both policies. A case study commissioned by the Ministry of Labor and Social Affaires in 1998 showed that more then 80,000 households misused the social safety net, mostly in connection

\footnotetext{
${ }^{9}$ Association of medical doctors filed a case against the dominant insurance company (VZP) at the Antimonopoly office.
} 
with unemployment and welfare benefits. The Czech Republic has less than 3 millions households in total and thus the misuse occurred in about $3 \%$ of them.

There were cases in the past when people registered as unemployed and received the benefits while working part-time or full time without a legal contract in the shadow economy, home or abroad. It may be questioned to what extend the officials were aware of the illegality of the claims.

More problematic from the corruption point of view might be the area of active policy. The rights of the district labor offices also define the possible ways of corruption. These rights include the selection of private businesses, which would receive a loan to retrain their employees, and also forgiveness of the repayment of the loan. The office can also provide aid to create jobs for fresh graduates or secured jobs and provide a loan to start a private business.

\subsection{Private Businesses}

The most visible forms of corruption in private (and also semi-private) businesses involve the selection of pre-specified partners in public tenders. In the banking sector corruption is associated with the provision of loans for unreasonable or even nonexistent projects. Such practices even led to the collapse of several banks and the loss of deposits. Bribes associated with corrupt behavior are not marginal and thus represent substantial costs. The distressing scope of such a phenomenon was revealed in the EBRD study (EBRD, 1999), which found that 26.3\% of Czech companies admit giving bribes. Czech companies spend, on average, $4.5 \%$ of their annual income on bribes. ${ }^{10}$

It would be misleading to think about corruption only in terms of extra monetary costs. Corruption in private businesses is accompanied also with time spent by managers. Kaufmann and Shang-Jin (1999) found that firms that pay more bribes are also likely to spend more management time with bureaucrats to negotiate regulations and thus face higher human capital costs. Such a finding is based on data from three worldwide firm-level surveys that do not include the Czech republic. However, we assert that bribe payments, management time wasted with bureaucrats, and the cost of capital may be positively correlated across Czech firms.

Another perspective of corruption in private businesses is associated with hiding parts of their activities in order to reduce tax payments. Such conduct requires additional cover-up steps that involve bureaucratic corruption. We do not have a representative survey for the Czech Republic; however, we can use some proxies from other European transition countries. McMillan and Woodruff (2000) conducted a survey among the private manufacturing firms about the size of hidden unofficial activity. The firm-level regressions for the three Eastern European countries, namely Poland, Slovakia and Romania, documented that bureaucratic corruption is significantly associated with hiding output.

\footnotetext{
${ }^{10}$ According to the study bribery is more prevalent in Poland and Hungary.
} 
Hiding output is closely connected with poorer tax collection by state administration. In another survey Johnson, Kaufmann, McMillan, and Woodruff (2000) found that the size of hidden unofficial activity to be much larger in Russia and Ukraine than in Poland, Slovakia and Romania. A comparison of cross-country averages has shown that managers in Russia and Ukraine face higher effective tax rates, worse bureaucratic corruption, greater incidence of mafia protection and have less faith in the court system than in more advanced transition counterparts.

\section{Measures of Corruption}

In the previous section we described and classified dominant forms of corruption according to different sectors of activity. Now we give a brief sketch on how such phenomenon is measured in two different ways.

There are two basic methods to measure corruption. The first one is based on the counts of discovered, monitored and prosecuted cases. It uses police statistics and statistics from the Department of Justice. Its major advantage is that these are hard numbers and well-founded figures. The disadvantage is that it is not able to measure latent corruption, i.e., the undiscovered cases. It means, that in the highly corrupted environment, where any true and independent investigation is impossible, such a measure can give an extremely low level of corruption.

Table 2

Question: Did you ever give a bribe in the following sector?

\begin{tabular}{|c|c|c|}
\hline Sector & $1989 *$ & $1998 * *$ \\
\hline Personal Services (hairdresser, etc.) & 61 & 45 \\
\hline Health Service & 42 & 31 \\
\hline Purchase of Durable Goods & 39 & 2 \\
\hline Repair Services & 36 & 37 \\
\hline Car Repair Services & 30 & 17 \\
\hline State Administration (any level) & 12 & 17 \\
\hline Housing & 11 & 4 \\
\hline Funeral Services & 9 & 1 \\
\hline To Put Child in a School of Any Level & 9 & 2 \\
\hline To Get a Job or an Advantage in a Job & 6 & 7 \\
\hline
\end{tabular}

The other method of measuring attempts to overcome the possible bias of the preceding method. Such a method involves opinion polls, surveys, and case studies. Table 2 gives an account of an opinion poll held in 1998 and 1998. It shows decline in giving bribes for goods and services as they became more available with transformation of the country towards market economy. State administration is the only category that recorded a significant increase. 
The above measures are less precise, however they more realistically reflect the situation in the country and/or particular sector. According to this principle, the Transparency International constructs the so-called Corruption Perception Index (CPI). The CPI has a maximum value of 10 , which means no corruption is perceived, while the value 0 denotes the most corruptive environment. The Czech Republic ranks in the middle of the surveyed countries, as well as Poland and Hungary. In 1998, the Czech Republic was $37^{\text {th }}$ out of 85 countries surveyed while a year later the country occupied $39^{\text {th }}$ place among 99 countries. The last survey from 2000 contained 90 countries and the Czech Republic was 42nd. Table 3 illustrates how the value of the index has evolved over past twenty years.

Table 3

Comparison of the Corruption Perception Index

\begin{tabular}{|c|c|c|c|c|c|c|c|}
\hline Country & $1980-85$ & $1988-92$ & 1996 & 1997 & 1998 & 1999 & 2000 \\
\hline $\begin{array}{l}\text { Czech } \\
\text { Republic }\end{array}$ & \multirow[t]{2}{*}{5.13} & \multirow[t]{2}{*}{5.20} & $\begin{array}{c}5.37 \\
(1.45) \\
\end{array}$ & $\begin{array}{c}5.20 \\
(0.47)\end{array}$ & $\begin{array}{c}4.8 \\
(0.8) \\
\end{array}$ & $\begin{array}{c}4.6 \\
(0.8) \\
\end{array}$ & $\begin{array}{c}4.3 \\
(0.9)\end{array}$ \\
\hline $\begin{array}{l}\text { Slovak } \\
\text { Republic }\end{array}$ & & & \multicolumn{2}{|c|}{ not evaluated } & $\begin{array}{c}3.9 \\
(1.6)\end{array}$ & $\begin{array}{c}3.7 \\
(1.5)\end{array}$ & $\begin{array}{c}3.5 \\
(1.2)\end{array}$ \\
\hline
\end{tabular}

Source: Transparency International. Note: Standard errors given in parentheses when available.

It is nothing to be happy about but according to the CPI the corruption environment in both the Czech and Slovak Republics is slowly gaining strength. Current forms of corruption have the same origin in the Czech and Slovak Republics due to their common experience in the former Czechoslovakia. The existing legal systems are also quite alike, which implies that if we observe one type of corruption in one of the Republics, there is a high probability that the very same corruption takes place in the other. Therefore, it is plausible to take known Slovak cases as supportive evidence.

Nevertheless, one of the main reasons for the split of the former Czechoslovak Federative Republic can be attributed to the uncontrolled power of the former Slovak political representation in 1992, which wanted to pursue privatization as a form of giveaways to its political supporters. Such practices are probably the major reasons why the CPI is almost one point lower for Slovakia compared to the Czech Republic, although the countries had the same starting point.

Constructing the CPI on a regular basis is only a small part of work that the Transparency International does to help fight corruption worldwide. The organization was founded in 1993 in Berlin, Germany, as an international organization to help fight against bribery and corruption. This non-governmental organization (NGO) aims to involve all components of civil society state administration, the private sector, entrepreneurs, and individual citizens - in creating a multilevel system against corruption. 


\section{Anticorruption Program of the Czech Republic}

In 1997 the Government of the Czech Republic assigned the Minister of Interior to "develop a concept of offensive methods for detecting corruption in civil service" (governmental decision No. 673/97 from October 29, 1997). Later on, the current administration defined a combat against corruption as one of its priorities. The original task, targeting corruption in the civil service, was extended by a Government Program of Combating Corruption in the Czech Republic (governmental decision No. 125/99 from February 17, 1999).

The great need to adopt the above measures was due to the past under the old centralized economic system as well as the passive approach of the state administration during the first years of the transition process. Indeed, such a state of affairs can be illustrated by the attitude of the public towards the government's responsibility in taking effective measures to prevent corruption. Table 4 presents results of an opinion poll carried out by GfK (1999) that is related to this matter.

Table 4

Question: Which government or governments, in your opinion, contributed to the spreading of corruption and bribery in our country?

\begin{tabular}{|l|c|c|}
\hline \multicolumn{1}{|c|}{ Government } & Years & $\%$ \\
\hline Communist Govt.'s. in the past & $1948-1989$ & 26 \\
Govt. (Federal) of Mr. Čalfa & $1990-1992$ & 5 \\
Govt. (Republic) of Mr. Pithart & $1990-1992$ & 4 \\
Govt. of Mr. Klaus & $1993-1997$ & 26 \\
Govt. of Mr. Tošovský & $1997-1998$ & 0 \\
Govt. of Mr. Zeman & $1998-$ present & 3 \\
None & 34 \\
\hline \multicolumn{2}{|c|}{ Source: GfK - Praha, 1999, N =1066. } \\
\hline
\end{tabular}

It is understood that the concept of anti-corruption measures must be systematically linked with steps that deal with other social problems. Combating corruption should be conducted in an organized way with the aim to prevent any new sources of corruption to emerge. No abrupt solutions should be taken because they could be counterproductive or even threaten the economy or civil rights and freedoms, instead of curbing corruption. Thus the goal of the Program of Combating Corruption is to:

1. describe the nature and objectives of combating corruption,

2. define its principal methods and means,

3. propose specific measures to be taken in respective areas,

4. define responsibilities and a time schedule, and

5. indicate the method of monitoring. 
As stated earlier the priority in combating corruption is to focus on corruption in the public sector, among top civil service officials, judges, state attorneys, policemen, customs officers, officials collecting taxes, and state control institutions. Such corruption is most dangerous for the stability of a country and could hinder an effective procedure against other forms of corruption and illegal activities. The Law on the Civil Service would be a systemic measure that could complement the Program in combating corruption in this area. Such a law should define the legal position and responsibilities of civil servants in the aforementioned administrative bodies, including limitations imposed on their other sources of income and their disciplinary liability. While being on the agenda, the Law did not materialize yet. A further objective of the Program is to deal with corruption in the private sector.

The program does not plan for any new institutions to be set up or new regulations to be adopted. Existing rules and institutions should be exploited instead, as well as the potential of the Czech civil society. In that respect, the program does not rule out possible cooperation of government with NGOs. If the situation calls for new institutions to be established, this would be based on a principle of minimum financial support from the state budget. The program aims to increase the extent of power for financial and tax authorities, as well as for police forces that deals with economic crime.

\subsection{Educational Program}

In order to increase awareness about corruption and the ability of civil servants to fight it, the government introduced an administration wide educational program involving officials from various administrative bodies. Three Ministries, the Ministry of Justice, the Ministry of Interior, and the Ministry of Education, Youth, and Sports, were assigned to work on several educational projects to increase awareness of the general public as well as civil servants.

The project on the national training of civil servants is focused primarily on preventing corruption. Another project focuses on education and discussion panels for police officers, state attorneys, and judges involved in corruption cases to provide detailed knowledge on corruption offences and relevant counteractions. More public oriented projects ask for preparation of various types of guidelines on social causes and consequences of corruption and methods of combating it, as well as the development of guidelines for civilian protection against corruption. As an ultimate goal these projects are aimed to increase the public awareness of the dangers of corruption in any form and to locate the means to investigate and prevent it.

Because the government program to combat corruption is of a relatively recent nature there does not exist long-term evidence about its usefulness yet. Therefore, we are unable to evaluate it properly at this time.

\subsection{Governmental program "Clean Hands"}

Czech political parties are connected with the economy in two principal ways. First, the members or persons affiliated with political parties form part of the management and supervisory 
boards in the companies where the state is able to control. Second, is through "loyal" persons that benefited from earlier phases of privatization thanks to their political connections.

The campaign "Clean Hands" was audibly launched in 1998 by the current government to deal with fiscal crime and corruption. So far it has drawn an enormous amount of bad reviews from opposition parties and media for its very limited success. The legitimacy and transparency of this campaign have been questioned when it was announced that the composition of the Investigating Committee would be secret. The campaign itself has produced less than 50 cases so far, with the former Finance Minister being the subject of one of them. It was admitted to be a failure and terminated in early part of 2000 .

In any event, the government in line with the promises made in its election program set up an inter-ministerial commission in September 1998. The major task of this body was to coordinate anti-corruption policy. Within a year the Commission was given more than 3000 cases of possible corruption to inspect. So far more than 200 complaints were filed with the prosecution. Police have inspected about 70 complaints out of these and only 20 of these have been handled in the criminal proceedings (EC, 1999).

The police refuse to prosecute a vast amount of the filed cases since the quality of the dossiers is questionable. Also, sometimes there is no clear evidence whether a particular behavior is prosecutable since it is not explicitly prohibited by the law although its nature might be "criminal" according to common sense.

\section{3 (Dis)improvement of legal system and proposed changes}

As the results of the new anti-corruption program are questionable and the governmental actions are lacking co-ordination, personnel and equipment resources, and appropriate legislation, the government decided to move in an easier direction. It proposed, and got approved in February 1999, an amendment to the Civil Code that increased the prison sentences for bribery from five to eight years.

Although the anti-money-laundering legislation is compatible with internationally required standards, there are several issues that need improvement. The tasks are divided among several agencies and Ministries and there is an obvious lack of sufficient coordination. The Czech Republic has neither signed the Council of Europe Criminal Law Convention on Corruption of January 1999 nor ratified the 1997 OECD Convention on Combating Bribery of Foreign Public Officials in International Business Transactions.

The proposed changes in the economic legislation comprise of property statements, changes in the monopoly regulation, further continuation of privatization and reform of public financing and financing of political parties. Additional changes include, for example, prescribed wire transfers above a certain amount. The extent of the new legislation is still a subject of political debate since it can substantially affect citizens' rights. 
Since the Czech Republic has a minority government and all legal changes require a majority support in The Parliament, there is a limited possibility for improvement. According to the 1998 European Commission report the achieved legal changes were unsatisfactory. Similar appreciation can be found in the 1998 World Bank Country Study on the Czech Republic. The European Commission went on to cast doubt on whether the Czech Republic would be able to reach the required legal standards in time to maintain its place in the group of "fast-track" accession countries. The reports of both institutions for 1999 were more favorable.

Nevertheless, the proposed changes are moving along the track of increased regulation and deterrence with high penalties but leave the current discretionary nature of economic regulation unchanged. Moreover, the intended changes would make the system less transparent, more complicated and, hence, increase the scope of possible corruption. As of now, there still exist special commissions at the Ministry of Finance and at the Ministry of Social Affairs and these commissions are allowed to forgive any penalties previously imposed at their discretion. These actions are completely unregulated, which opens a space for high-level corruption.

The government assessment of suggested remedies to corruption is based on old concepts of deterrence and does not involve the assessment of potential hazards introduced to the system nor the analysis of the existing ones and their elimination by a simple change. Therefore, we are quite skeptical about the positive effects; we expect that the implementation of all the suggested enhancements would create even more problems with corruption than solutions.

The Parliament also passed a Free Information Act. This act shall allow access to all state information with the exception of classified data. On the other hand, the current practice is that the bureaucracy is asking excessive "processing" fees to prevent the revealing the information.

The unsubstituable role of free media in corruption prevention and policy supervision revealed itself during the crisis in the public television in December 2000. Czech Television is financially independent on state budget, however the Czech Television Council answers to the Czech Parliament. The recently nominated Council for Television Broadcasting has elected, in a hasty procedure less than two days long, on December 20, 2000, a new CEO of Czech Television. Part of the staff of the Czech TV opposed the election and began a strike. The main objections were: the Council was nominated based on political premises and consisted chiefly from members of political parties; candidates for a new CEO were subject to political negotiations held between the two major parties prior to the election. Both deeds were against the Czech Television Act governing its independence from the state. The new management started to fire protesting TV staff and commenced regular censorship of news broadcasts, along with switching-off TV broadcasting entirely. A several week long standoff peaked by the resignation of the new CEO in between two extraordinary sessions of Parliament. In January 2001, the deputies approved the new Czech Television Act and called down remaining members of the Council for Television Broadcasting. They also named an interim CEO. Paradoxically, the new version of the Czech Television Act even strengthens the influence of the political scene on television operation. 
According to political scientists the situation reflects a deep political crisis in society. Political control of independent media constitutes an enormous potential for corruption and rent seeking. In the case of Czech $\mathrm{TV}$ a spontaneous civic reaction prevented, probably just temporarily because of the flaws of the new Act, such a development.

In the summer of 1988 and 1989 the Institute of Business Research performed studies measuring the gray economy of the inefficient socialist society at that time. GfK-Praha, Ltd. obtained similar sets of data in 1998 (GfK, 1998). A comparative analysis of the two timeseparated data sets suggested that instances of corrupt behavior are declining. The Transparency International (1999) published detailed comparison in the analysis "The State of Corruption after Ten Years". Despite such findings, the area of (government) clerical services have become the most corruptible institutional environment in the eyes of Czech citizens.

However, we should not be overly optimistic because, as the report states: "The transformation of corruption from the sphere of general services and sales to state clerical services, together with the socially differentiated nature of the evaluation of the necessity of bribery, signals a change in the social function of corruption. Earlier, corruption primarily assured a better level of services and a supply of shortage goods. Today, a category of people is crystallizing for whom corruption is a working tool necessary for professional success. The current common trend is towards the concentration of corruption in the state administration and the creation of a group of people whose existence is strongly dependent on corruption." And the aforementioned TV crisis puts another perspective into this conclusion.

\section{Concluding Remarks}

The article should help the reader understand why the Czech Republic is systematically ranked the lowest in comparison with Central European countries with respect to the quality of the institutional environment and governance structure (e.g., Chapter 6, EBRD, 1999). In the absence of proper institutional mechanisms and sufficient protection of ownership rights the free market creates more opportunities for economic contests and economic manipulation. These are the roots of the problems and the remedies should focus on these underlying problems instead of problematic and ineffective campaigns fighting just the consequences.

The more complex the system is the more likely are different loopholes, backdoors and contradictions. Once the state becomes unable to enforce every part of the law because of whatever reason, its reputation suffers. As in a devilish spiral, to improve its reputation it has the tendency to use more and more complex regulations - that again it is not able to fully enforce. In this environment of rapid and unsystemic fixing of problems the quality of the legal framework deteriorates and, in addition, the lobby groups are better able to pursue exceptions (of whatever quality and reason) into the existing legal framework. A rent-seeking behavior becomes 
encouraged just to meet the "exception" rule. ${ }^{11}$ Proper means of lobbying are replaced by its shadow counterparts, if not corruption.

The best prevention of corruption is not only to make all procedures completely transparent, simple and lucid, but also, more importantly, to establish such an environment that minimizes the incentives to go around the rules even in the absence of punishment. One final positive example of such a successful change: In the early nineties there were real problems to obtain a passport within several days in case of emergency, and informal ways to speed up the process had to be used. Currently, the people who need a passport to be issued earlier than within the regular 30 days can choose among faster services with different fees. There exist no incentives to go around the rules and even the state is able to collect additional fees.

The overall impression favors the persistent presence of corruption within the society and economy of the Czech Republic. Numerous comparative studies, however, suggest that corruption is a more prominent feature in other transition countries, with the former Soviet Union leading the pack. Nevertheless, the state of corruption in the country, measured by the Corruption Perception Index, presents a serious problem since the index does not improve as the transition process advances. We believe that a substantial change of approach to the institutional framework is necessary in order to prevent and fight corruption successfully.

\footnotetext{
${ }^{11}$ For example, the current amended version of a relatively simple Income Tax Act of 1992 is now so complex and linked with other laws that it now contains more than two hundred times the phrase "with exception of".
} 


\section{REFERENCES}

Acemoglu, Daron and Thierry Verdier, (2000): "The Choice between Market Failures and Corruption," American Economic Review, 90(1), pp. 194-211.

CESTAT (1999): CESTAT Statistical Bulletin, Czech, Hungarian, Polish, Slovak, Slovenian, and Romanian Statistical Offices, various issues, Prague.

EBRD (1999): Transition Report, European Bank for Reconstruction and Development, London.

EC (1999): Accession Report on the Czech Republic, European Commission, Brussels.

GfK (1998): "Korupční klima v ČR - Retrokorupce (Corruption Climate in the Czech Republic Retrocorruption)". GfK Prague, Internal Report No. 90.276.

GfK (1999): " Korupční klima v ČR 2 (Corruption Climate in the Czech Republic 2)". GfK Prague, Internal Report No. 40/151.

Johnson, Simon, Daniel Kaufmann, John McMillan, and Christopher Woodruff, (2000): "Why do firms hide? Bribes and unofficial activity after communism," Journal of Public Economics, Amsterdam, 76(3), pp. 495-520.

Johnson, Simon, Daniel Kaufmann, and Pablo Zoido-Lobatón (1998): "Regulatory Discretion and the Unofficial Economy," American Economic Review, 88(2), pp. 387-392.

Johnson, Simon, John McMillan, and Christopher Woodruff, (2000): "Entrepreneurs and the Ordering of Institutional Reform: Poland, Slovakia, Romania, Russia and Ukraine Compared Source," Economics of Transition, 8(1), pp. 1-36.

Kaufmann, Daniel and Shang-Jin Wei, (1999): "Does 'Grease Money' Speed Up the Wheels of Commerce?," NBER Working Paper No 7093.

Kočenda, Evžen, (1999): "Residual State Property in the Czech Republic," Eastern European Economics, 37 (5), pp. 6-35.

Kočenda, Evžen, and Štěpán Čábelka, (1999): "Liberalization in the Energy Sector: Transition and Growth,” Osteuropa Wirtschaft, 44 (1), pp. 104-116.

Lacko, Maria, (2000): "Hidden economy -an unknown quantity? Comparative Analysis of Hidden Economies in Transition Countries, 1989-95," Economics of Transition, 8(1), pp. 117149

Lízal, Lubomír, (2000): “Koordinace ekonomické politiky ČR v sít’ových odvětvích a praxí EU 
(Coordination of the Czech Economic Policy in Network Industries with Practice in the EU),“ Finance a úvěr, 9, pp. 488-502.

Lízal, Lubomír and Jan Svejnar, (2000): "Financial Conditions and Investment during the Transition: Evidence from Czech Firms," CERGE-EI Working Paper \# 153.

Mauro, Paolo, (1995): “Corruption and Growth," Quarterly Journal of Economics, 110(3), pp. 681-712.

Mauro, Paolo, (1998): "Corruption and the Composition of Government Expenditure," Journal of Public Economics, 69(2), pp. 263-79.

OECD (1999): OECD Communication Outlook, OECD, Paris.

Rose-Ackerman, Susan, (1999): "Corruption and government: Causes, consequences, and reform," Cambridge University Press, Cambridge, New York and Melbourne.

Stiglitz, Joseph, (1999): "Whither Reform," Annual Bank Conference on Development Economics, Washington, DC, April 28-30, 1999.

Tanzi, Vito and Hamid Davoodi, (1997): "Corruption, Public Investment, and Growth," IMF Working Paper WP/97/139.

Turnovec, Frantisek (ed.), (1999): Czech Republic 1998, Facing Reality, CERGE UK, Prague, January.

Transparency International (1999): The State of Corruption after Ten Years. http://www.transparency.cz/english/state.html.

World Bank (2000): Anticorruption in Transition: A Contribution to the Policy Debate, The World Bank, Washington, D.C. 